\title{
THE FANTASTIC HOLE: TOWARDS A THEORISATION OF THE FANTASTIC TRANSGRESSION AS A PHENOMENON OF SPACE
}

\author{
Patricia García \\ Trinity College Dublin/Dublin City University \\ patricia.garcia5@mail.dcu.ie
}

Recibido: 18-02-2013

Aceptado: 29-04-2013

(c) (1) (9)

\begin{abstract}
This article develops a theoretical foundation for a type of fantastic transgression that occurs due to the incursion of an impossible spatial element within a realistic frame shared by narrator and reader. A variety of 19th, 20th and 21st century short stories and short films are examined to establish a theoretical outline for this transgressive phenomenon, here denominated «the fantastic as a phenomenon of space», or «the fantastic of space». Three categories of this phenomenon are proposed: the transgressions of the «body» and the notion of being (physically and existentially) in space, of the «boundary» and the principles of definition and circumscription, and «hierarchy», related to the dialogue between container and contained. Ultimately, these three categories meet within one single motif: the fantastic hole, presented as a paradigmatic spatial distortion of the fantastic as a phenomenon of space.
\end{abstract}

KEYWORDS: fantastic, space, transgression, geocriticism.

\section{RESUMEN}

El objetivo de este artículo es establecer la base teórica de una transgresión fantástica que aquí será denominada «lo fantástico del espacio». Esta transgresión se caracteriza por la violación de las leyes físicas y lógicas que gobiernan nuestro sentido del espacio. Ya que en los estudios teóricos de lo fantástico la dimensión del espacio no ha sido considerada posible elemento de transgresión, este artículo plantea tres categorías claras de transgresión fantástica como fenómeno del espacio: «cuerpo» y la noción de estar y ser (física y existencialmente) inscrito en el espacio; «frontera», de la que derivan principios como la definición y circunscripción; y «jerarquía», relacionada con el diálogo entre continente y contenido. Finalmente, estas tres categorías espaciales confluyen en un motivo: el del agujero fantástico, que se presenta como figura paradigmática de «lo fantástico del espacio».

PALABRAS CLAVE: Lo fantástico, espacio, transgresión, geocrítica. 
Introduction: the Fantastic as a Phenomenon of Space

I have elsewhere discussed the importance of the notions of place and space within the studies of the fantastic (García 2013a, 2013b). In an article entitled «The Fantastic of Place versus the Fantastic of Space» (2013b), I traced a distinction between two theoretical models. In the «fantastic of place», a particular place acted as host of the supernatural, a paradigmatic example being the trope of the haunted house, as observed in texts such as The Manuscript Found in Saragossa (Jan Potocki, 1804) and E.T.A. Hoffmann's «The Deserted House» (1817). The haunted house, deriving from the Gothic ghost story, is a recurrent motif in enhancing the premonitory action: it is a trope that frequently evokes the desired disturbing atmosphere and invokes the supernatural. However, it has to be born in mind that no matter how important the atmospheric function of the haunted house is in the story, the place itself is physically normal and not impossible in accordance with our laws of physics. Although the place of action might initially be presented as exceptional —as is the case of «The Nameless City» (H.P. Lovecraft, 1921) and Jorge Luis Borges' city of «The Immortal» (1949) — generally it is later revealed that this anomaly is due to the exceptional phenomenon it hosts and not to its own physical impossibility. Instead, as in the classic motif of the haunted house, another element (the ghost, for example) breaches the realistic laws.

In the second modality, «the fantastic of space», the dimension of space was directly involved in generating the supernatural. It was an active agent of the fantastic transgression in that some element of it was in itself impossible. An excellent example of this category is «La casa» (1975), a Kafkian short story by Peruvian author José B. Adolph, which describes how a random house devours a random individual. The question of where this house is located -its specific coordinates and attributes - is not as relevant as the impossible action this house is performing. Therefore, in «the fantastic of space», the impossible element instead of taking place in space is an event of space, bound to some architectural element or to the — normal, logical — physical laws governing this dimension.

The previous articles were a first step towards the thesis that narrative space can provoke a fantastic transgression of the impression of realism. As I showed, scholarship of the fantastic had approached narrative space from various angles but there had been no comprehensive study specifically on how the dimension of space is involved in the disruption of the realistic effect. ${ }^{1}$ On the other hand, scholarship on space in literature had been predomi-

1 Examples of scholars dealing with the dimension of space in fantastic narrative are Jackson (1981), 
nantly centred on realistic texts, devoting very little attention to the fantastic, which itself was frequently understood as a synonym of any form of the supernatural. ${ }^{2}$ My conclusion was that a further insight into «the fantastic of space» was needed. Since not all transgressions of space are one, a more extensive analysis would benefit from the different thematic variations that this phenomenon offered. This task would necessarily imply a more extensive reflection on how space intervenes in the human - and textual- construction of reality.

The present article can be viewed as a follow up to these previous conclusions; it provides a closer insight into the model of «the fantastic of space». The described physical spaces in the text will be here not only the scene of actions («the fantastic of place») but also the impossible elements performing the fantastic transgression within the fictional reality («the fantastic of space»). The central issue concerning this article is thus: in what forms can space transgress the mimetic effect, and so lead to the fantastic effect? This refers to a question that has already gained some prominence in literary criticism, which is: how does space help build the impression of realism in narrative? In other words: how is a «real space» narrated?

The existing corpus provides a unanimous answer to this question. Darío Villanueva in his work Theories of Realism (1997), Bertrand Westphal in Geocriticism (2007) and, in the context of fantastic narratives, David Roas in his introduction to Teorías de lo fantástico (2001) and in his latter theoretical work Tras los limites de lo real (2011), all converge in one aspect: referentiality is the key notion in building a sense of realistic space, in that the reader contrasts the extratextual space with the spaces depicted in the literary world to establish that they are both similar (until the supernatural irrupts, in the context of fantastic fiction). The fantastic always presupposes a previously constructed textual reality that imitates our extratextual reality. That intratextual reality is perceived as realistic by the reader who constantly contrasts it with his referential one.

The notion of referentiality between fictional and factual space is clear for a realistic text but how is the lack of spatial reference constructed in a fan-

Aguirre (1990), Campra (2001) and Fournier Kiss (2007). For a more detailed review of existing scholarship, see the first part of my article «El espacio como sujeto fantástico: el ejemplo de "Los palafitos" (Ángel Olgoso, 2007)» (2013a).

2 For example the proponents of the Theory of Possible Worlds (Pavel 1986, Ryan 1991, Doležel 2008) reflect an ambiguous understanding of the fantastic as an umbrella term for the supernatural. Doležel, for instance, does not make any distinction among supernatural worlds, as if taking for granted that all forms (science fiction, the marvellous, the mythical, the fantastic) had the same macrostructural construction. 
tastic text? In order to tackle properly the question of how space intervenes in the construction/destruction of this mimetic contract, perhaps a more e-lemental question should be first considered, it being: how does the human sense of space help build the human sense of reality?

This cannot be answered without taking into account key notions of human space developed in Human Geography, Phenomenology of Space and Anthropology. Studies such as those by phenomenologist Maurice MerleauPonty (1945), philosopher Martin Heidegger (1951), anthropologist Otto Friedrich Bollnow (1963) to mention only the theorists which will be discussed here in relation to the fantastic, have convincingly argued that space is a fundamental category in human experience: our apprehension of space directly influences our apprehension of reality. Their views will be briefly compiled into three categories to demonstrate how they are applicable to the study of fantastic transgression.

\section{Transgressions of the Body in Space}

The first category of space discussed here in relation to the fantastic refers to perhaps the simplest, and yet most fundamental, principle of human spatiality: we are in space. And this notion of being in space is as much physical and situational as it is existential.

The space/body/subject triad has proved to be central in the schemes of the real interpreted under the lens of Phenomenology and Existential Philosophy, as seen in, for example, Maurice Merleau-Ponty's philosophy on spatiality of —and in — human existence, and in Martin Heidegger's existential approach to space, particularly as exposed in his piece «Building, Dwelling, Thinking» (1951).

In his work Phenomenology of Perception (1945), Merleau-Ponty extensively elaborates on the perception of reality through the corporeal. He develops a phenomenological insight into reality, understood as an experience mediated through our senses. At the heart of this experience, he argues, is the body. In his view, the human body is a starting point that anchors all spatial relationships and experiences of distance, direction and location: «When I say that an object is on a table, I always mentally put myself either in the table or in the object, and I apply to them a category which theoretically fits the relationship of my body to external objects» (1962: 101, emphasis in the original).

As expressed in this quote, physical space is an experience both perceived and constructed by the individual's corporeal awareness. Of particu- 
lar significance are the notions of dialogue and interrelation between space and body - two entities that need each other to construct the experience of material reality. That the spatial environment is produced by the subject and the subject is produced by space is the core idea of Merleau-Ponty's work, captured by formulas such as «the body is our anchorage in a world» (1962: 144), or «the body is our general medium for having a world» (1962: 169). From this angle, the human experience of reality is inextricably linked with how the body perceives space, and conversely with how it perceives itself in space.

The existential awareness of «being» (a «subject») through this dialogue between body and space is the pivotal thought of Martin Heidegger's essay «Building, Dwelling, Thinking». As the title indicates, Heidegger elaborates on the existential relationship between being and dwelling, originating from our experience of the built environment. By «dwelling», he means inhabiting the world. But more importantly, the corporal experience of «being in space» is equated with the act of being aware of the self. In other words, the subject perceives himself by the space he occupies. The notion of «being» for Heidegger inseparably encompasses this double existential and situational dimension, an opposition that, unlike other languages (e.g. the Spanish ser and estar), the German (and the English) language merge into one single verb: sein (to be). Heidegger resolves this by simply adding a spatial deictic («da», German for «here» and «there»), resulting in his central term Dasein.

The German philosopher thus stresses the interrelation between ontology and position, between being and being there, and this ontological aspect to being in space is the core of the fantastic transgressions of the body in space. To know that we exist is to know that we have a body that inhabits space and generates space, a thought that coincides with Merleau-Ponty's view of corporeal perception as a way of stating «I am in the world».

What these phenomenological and existential analyses of space recall is that the notion of physical reality (whether textual or actual) cannot be segregated from that of emplacement, or physical position. As much as there is no space without a body that experiences it, as Merleau-Ponty argues, there is also no body if there is no space for it to be in.

In the literary realm, in the volume Raum und Bewegung in der Literatur (Hallet \& Neumann, 2009) —dealing, as the German title indicates, with space and movement in literature - the editors emphasise how the notion of spatiality (Räumlichkeit) is correlated with that of spatial experience (Raumerfahrung): there is no space without movement, this latter perceived as the dynamic act of a subject who observes it and not necessarily as physical displace- 
ment around it (2009: 20-21, 66). Accordingly, space cannot be dissociated from the corporal experience of the one who perceives it. For this reason, the codependence of «body» and 'narrative space' should be taken into account in any study on textual spatiality.

In the realm of fantastic fiction, many short stories can be evoked to show how this basic relation of body in space is breached. As a result, the fantastic transgression derives from a failed inscription of the human body in space, frequently leading to a new existential plane, or to an existential redefinition of the subject. An example is the aforementioned «La casa» (José B. Adolph, 1975), an anthropophagous space that progressively devours the body of its inhabitant, who, to the reader's surprise, celebrates his forthcoming state of being without a body. Other sample texts are «El museo» (José María Merino, 1982) and «La habitación maldita» (Fernando Iwasaki, 2004), where the force of the space prevents the subject from leaving or moving freely inside and out of it. This museum-house in the first case, and hotel room in the second, entrap the main character, who literally becomes part - and property - of that space. The same motif of a space which acts as a magnet to the body is found in short stories such as Stephen King's «1408» (2002), in which a doomed hotel room tortures he who is inside, manipulating his thoughts and preventing him from leaving, or in novels like The Haunting of Hill House (Shirley Jackson, 1959), the title of which refers to a mansion which decides when and how things occur inside («The gates are locked. Hill House has a reputation for insistent hospitality; it seemingly dislikes letting its guests get away», 1999: 67).

The most literal representation of the disappearance of the subject in space is found in a short story by British writer James Graham Ballard called «The Enormous Space» (1989). In it, a man isolated from the world narrates how he slowly feels himself dissolve into the space of his house or, as he puts it, ceases to be who he was to «become» the house.

A similar fantastic transgression takes place in «Valle del silencio» (1982) by Spanish author José María Merino. The disappearance of Marcellus is later «resolved» when his friend realises he has fused into the rock of a cave: «[...] under the humid moss that Lucius Pompeius' fingers separated, an eyelid appeared and an eye opened after that amazement of absolute selfabsorption. [...] Marcellus' body had incorporated in the very substance of the valley» (1982: 84). ${ }^{3}$

3 All translations from non-English short stories non-referenced in the bibliography are mine 
Another character who undergoes a similar fate is the narrator of «Le Corps éparpillé» (1991) by Quebecois Michel Dufour, who wakes up one morning to feel his body not only dispersed all over the room, but being each object in it: «Besides, in my position, I cannot go too far. As an object that one ends up forgetting by force of habit, I am from now on part of the setting» (1991: 100).

As a last example of this category, the short film Marisa (2009) by Spanish director Nacho Vigalondo is worth mentioning. It starts with the story of a woman, Marisa, whose mood oscillates according to the different places she is. While this might seem quite ordinary initially, her gets more complicated when the narrator tells us that after a while her entire persona becomes susceptible to the changes of position in space: depending on where she is located, she becomes different Marisas («her changes of personality related to her position in space, with a sensibility of less than a square meter», narrator in Marisa). The narrator's struggle to find «his» Marisa, and thus her specific physical position in space, starts here: after a while, he discovers her specific coordinates, which turn out to be in a playground quite far from their home town. At this stage, the fantastic has already irrupted, with a transgression of the notion «being in space»: Marisa is different people, depending on where her body is located. When Marisa is at the playground, she is the person whom the narrator had met: «his» Marisa. Therefore, position literally encompasses physical as well as existential emplacement. «To be out of place» is interpreted literally in this short film as being someone else. The situation gets even more complicated: Marisa starts changing identity even when she is still in the same spot. At that particular moment, the narrator realises that he would have to find Marisa not only in the right place but also at the right time.

If the body is a central referential axis for man to apprehend the physical space around him, this apprehension is realised by demarcating himself from the external world (hence the double physical-experiential dimension). The process of demarcation inherently refers to the notion of «boundary».

\section{Transgressions of the Physical Boundary Between Spaces}

In order to apprehend what surrounds us -that which we call «reality»- we strive to articulate it in a more or less coherent system. In this process, a central spatial ally is the notion of boundary. An illustrative example of this phenomenon goes back to the historical evolution of the concept of space from the Middle Ages to the Renaissance. It is in this last period that 
the rise of geographical knowledge was made possible largely through the techniques of measurement of physical space (and time): the compass, the telescope and the Ptolemaic map brought drastic changes that reconfigured the world-view. As David Harvey reminds us, the Ptolemaic map played a central role in the Renaissance, since it located all the countries of the world in a single spatial frame, and in so doing presented «the globe as knowable totality» (1990: 246). By imagining what the globe would be if looked at by a human eye, Ptolemy was also implicitly reasserting an alleged «objectivity» of optics and the capability of the individual to represent truthfully what he or she sees. Through a (supposedly) objective representation, space was conceived as containable and conquerable, and what is more important, reality would be something «objective» that all viewers would share (a thought completely refuted in Postmodernity).

This delimitation of space through knowledge - which equates to an alleged domination of reality: space, time and nature - was a necessary condition for human development. It favoured the emergence of some of the most influential theories on spatiality (Copernicus, Galileo, Descartes), culminating in the scientific revolution of the seventeenth century, in particular the Newtonian theory of space and time being absolute categories.

This need for delimitation became a synonym of knowledge and control over reality. A similar phenomenon is already found in the scheme of the real of Ancient Greece. The horos, «boundary», «limit» or «frontier», is what articulated the otherwise boundless and chaotic something. The jorismós, or horizon, was the limit of physical space that the eye could meet (the Kosmos), and beyond this articulating boundary laid the inapprehensible: the infinite (the Kaos). ${ }^{4}$

The field of Anthropology of Space offers plenty of other examples of how, in the history of humanity, the experience of the real has been equated with that of bounded space. Anthropologist and philosopher of space O.F. Bollnow explains how the horizon - a fusion between the body and the boundary as axis of the spatial experience- was a physical as well as an ontological limit for many ancient civilisations: «[...] beyond the borders of the known inhabited realm, the world simply stops», 2011: 60). Drawing on previous explorations of the concept of space in ancient Egypt, Bollnow em-

4 The Platonic jorismós is the boundary between the world of ideas and the physical world. Most interesting here is Aristotle's view of the jorismós as that which divides the Physis (that which is seen) and Metaphysics (that which cannot be seen). Beyond that jorismós, scientific knowledge is impossible. Therefore knowledge is equated and dependant upon the jorismós. There is no science beyond and without that boundary (Le Problème de l'être chez Aristote, Pierre Abuenque, 1962). 
phasises that only the space delimited by the human eye was conceived as an ontological possibility, as «reality». Beyond that founded terrain was the surrounding chaos, conceived as an unknown domain that did not belong to the real. Rather than a «space», this chaos was «space-less» (2011: 61).

It is through the notion of a referential boundary that spatial oppositions such as «up/down» and «in/out» are conceived. Without this boundary, space becomes an incomprehensible and unattainable «something» and, in the absence of any referential system of coordinates, the notion of distance and location would have no meaning. As Roas reminds us, man needs to «enclose [acotar in the Spanish original] his world in order to function in it» (2011: 35). As a result, the human perception of reality necessarily needs a stable and referential boundary through which orientation, measurement and articulation are made possible.

In the fictional storyworld, this notion is related to narrative frames that structure the different spaces composing the recreated physical environment. Having established that the «boundary» is a crucial device for the human in the experience of space, it is easy to understand why it is also an important realistic device within the fictional text. This impression of realism constructed by a set of spatial frames is precisely that which the following fantastic texts destabilise. ${ }^{5}$

Within the corpus of the literary fantastic, there is a large variety of narratives calling into question the boundary as constructing relations of distance, reference and location. Quim Monzó’s «La força centrípeda» (1996) and David Roas' «Excepciones» (2010) are clear and complementary examples of this. The first story describes a man who finds himself back in his living room every time he tries to cross the threshold out of his house. Roas' story is its antagonist; he even dedicates his text to Quim Monzó («to Quim Monzó, from the other side of the threshold», 2010: 135). In it, every time the protagonist tries to cross the threshold into his house, he finds himself outside again. It can be noted how the threshold in these two short stories functions as a destabilising agent: instead of framing space - living room/corridor, or street/ hall - it transgresses the expected delimitation between places.

Another interpretation of the transgression of spatial boundaries is found in texts which play with the idea of a lack of boundary and so of cir-

5 This is the principle used in the impossible buildings painted by M.C. Escher (e.g. Belvedere Lithograph, 1958), by Giovanni Battista Piranesi's Prisons (1750) or Sandro Del Prete's Inverted Chessboard (1975). In all these constructions, the very notion of boundary for «inside/outside», «here/there» and «above/ under» is cancelled out. This gives rise to a series of visual topological paradoxes. 
cumscription. Boundless structures are the railways on which the trains of «Tandis que roule le train» (Éric Faye, 1997), «Le Tunnel» (Jacques Sternberg, 1974) and «La Sanction» (Jacques Sternberg, 1974) circulate. The passengers' anxiety derives from the fact that they are on a journey with no envisaged end. They roll on a seemingly endless railway recreating the vertigo of an infinite, unbound structure, where no reference is permanent or reliable and no end is conceivable.

There are also examples of this type of transgression in cinema. In an animated short film entitled Skhizein (Jérémy Clapin, 2008), Henry, the protagonist and narrator, tells of how a meteorite has impacted his life: he is now «exactly ninety-one centimetres from [himself]» narrator in Skhizein. A second meteorite displaces him further: where the first one had provoked a slippage sideways, this second one provokes a slippage of seventy-five centimetres downwards. As a result, he has to learn to live literally displaced from all the objects and people which surround him. The distances he experiences are not the real ones; the referential system of coordinates he had until now, shared with the rest of humans, is not valid anymore. He now has to learn to mark new distances with chalk to avoid bumping into objects and people. After his displacement, Henry emphasises how he would like to reverse the slippage and find his place once again, expressing his desire to return to the common shared system of references of distances between things in space.

\section{Transgressions of Spatial Hierarchy and Containment}

Apart from the notions of distance and definition, there is a further aspect deriving from the relational system of boundaries which needs to be examined. This aspect concerns the organisation of spaces in a hierarchical order, and thus how this expected hierarchy can be transgressed. It is useful in this sense to recall Ryan's definition of literary spatial frames as: «the immediate surroundings of actual events, the various locations shown by the narrative discourse or by the image (Ronen's "settings" [1986]; Zoran's "fields of vision" [1984])» (Ryan, 2013: 9). These surroundings are delimited by spatial boundaries (clear-cut or fuzzy) and are also «hierarchically organized by relations of containment (a room is a subspace of a house)» (Ryan, 2013: 9).

Logically, but perhaps not remarked upon enough, the order in which spatial frames are classified hierarchically is fundamental to generating the realistic effect within the literary text. When presenting or presented with a literary world that follows realistic conventions, the author or reader per- 
forms this process almost automatically, in that it is recognised or assumed that, for example, Raskolnikov's garret (Crime and Punishment, 1866) is contained in a larger structure: the guesthouse. This guesthouse is at the same time part of a larger frame (the city of St. Petersburg), which also belongs to a broader container, etc. ${ }^{6}$

Among the most studied obliterations of hierarchical systems in postmodern literature are those of metalepsis and metafiction. If, by logic, textual reality is part of extratextual reality, a large variety of texts seek to challenge this hierarchical relation, particularly playing upon hierarchies concerning embedded fictional levels. Jumps, loops, recursion, infinite regress and selfreferences among the interplay between fictional levels are forms of disrupting the principle of spatial hierarchy.

The scholarship dealing with these transgressions in the fantastic (Brooke-Rose, 1981; Erdal Jordan, 1998; Horstkotte, 2004; Rodríguez Hernández, 2010) has emphasised that these strategies represent the fracture between language and reality after the Language Turn or, as Erdal Jordan puts it, they «impose the linguistic reality as option over the empirical one» (Erdal Jordan, 1998: 123). In a fantastic mode, the strategies of metalepsis and metafiction have been exploited by the canonical text of «Lost in the Funhouse» (John Barth, 1968), where the protagonist is entrapped in a funhouse that is equated with the space of a book that never ends. Also in another text, "Continuidad de los parques» (Julio Cortázar, 1956), what the character reads has an effect upon the space from which he is reading it - the reality of the character. This transgression violating the principle of containment of the fictional text within factual reality reflects Derridean ideas concerning the autonomy of the text in relation to the real, the pure self-reflexivity of language and the absence of all implication of the text in the world.

An interesting variation of the traditional metalepsis in the fantastic replaces the embedded fictional level with virtual space. The jumps across hierarchical levels take place between the realistic domain and the virtual. This leads to plots where, for example, cybernetic creatures trespass into the realistic domain within the text, such as the artificial monster of «Intimidad cibernética» (José María Merino, 2002), a creature that one day replaces his creator.

6 Note how narrative space, in particular the various embedded spatial frames, is employed in the opening of Crime and Punishment to locate the reader in a verisimilar space: "On an exceptionally hot evening early in July a young man came out of the garret in which he lodged in S. place and walked slowly, as though in hesitation, towards K. bridge. He had successfully avoided meeting his landlady on the staircase. His garret was under the roof of a high, five-storied house and was more like a cupboard than a room» (Dostoyevsky 2000: 3, emphasis added). 
Other texts disrupt automatic associations of spatial relations of containment, not of embedded fictional levels but exclusively of space presented as physical within the storyworld. To start with, a classic example is the eggshaped object of «The Crystal Egg», by H.G. Wells (1897). This transparent egg transgresses the logical principle of spatial hierarchies since, despite its relatively small dimensions, it contains a whole society of Martians.

Inspired by this short story, which borders the confines of science fiction, is Borges «The Aleph» (Jorge Luis Borges, 1949). The narrator of this wellknown short story discovers in the basement a point in space containing all possible angles of the world: «Each thing (a mirror's face, let us say) was infinite things, since I distinctly saw it from every angle of the universe» (1999: 192). This sort of (key)hole enables a total view of space and time; it contains the world, accessible from an absolute gaze. The transgression of the physical laws of space which Borges is presenting is thus based on the following two paradoxes: the first is the same as that exemplified by the crystal egg. The aleph, physically speaking, has constricted specific dimensions - like a keyhole, we imagine- but at the same time it is the container of a space larger than itself. Second, the contained is not only larger but is total and absolute, representing the paradox of containing the infinite within the finite. This is the logical problem encountered by the narrator when he has to describe the aleph: how can he express an infinite image within the finite extension of words and the limited dimensions of the page?

The figure of the aleph confronts the narrator and reader with a vision where all spatial (and temporal) tools (e.g. orientation, reference and selection) that human beings possess to make sense of physical space and to represent it are eradicated. To express this impossible vision, the narrator employs different rhetorical devices: disjointed reiterations, lists of enumerations of what he simultaneously sees («I saw»), absolute quantifiers («each», «every», «all») and, most interestingly for this analysis, a juxtaposition of the relationships of containment. Thus, the part and the whole are placed in the same hierarchy: «a copy of the first English translation of Pliny [...] and all at the same time saw each letter on each page» (1999: 193). «The Aleph», inspired by Wells' egg containing an entire world, represents a reduction of the space of the world by inverting the relation of whole and part, container and contained.

A large part of Borgesian fictions are based on the same principle of making «the large fit into the small». It is found in «The House of Asterion» (1949): «Each part of the house occurs many times; any particular place is another place. [...] The house is as big as the world-or rather, it is the world» 
(1999: 221), and in «The Man on the Threshold» («There is a saying, you know — that India is larger than the world», 1999: 270). Also «The Library of Babel» (1941) and «The Book of Sand» (1975) and are further examples of structures that play upon the principle of container-contained, finite in their physical dimensions and infinite in what they contain; where each part contains the whole and the whole is simultaneously part of itself.

Another variation of the transgression of logical spatial hierarchies is what could be called the motif of the self-enclosed space. An excellent example is «Dejen salir» (1982) by Spanish author José Ferrer-Bermejo. This short story proposes a cancellation of hierarchies by interlocking various spatial frames. This turns into a Möbius effect, a self-referential structure - a metro station - where inside and outside lose their polarity. The story tells of the following event: the character and focaliser of «Dejen salir» is confined within a metro station in the city of Madrid. There seems to be no way out, as the title indicates, since he is constantly drawn back to his point of departure. Already entrapped in this looping space when the narration starts, he finally surrenders and accepts that it is not a lapse of concentration on his part but a fact: no matter how many tunnels he goes across and stairs he goes up and down, he always ends up at the same point of departure, with the same scenes repeating over and over again. There is no access back to the street and the city, which would be the higher level in the spatial hierarchy: there is no outside or inside, since it is all one single self-referential surface. The spatial dichotomy of in/out is thus invalidated: since «inside» is not a possibility for the character, «outside» loses its meaning in opposition to it.

To conclude the outline of «the fantastic of space», the focus will turn to a recurrent trope in the fantastic where the three categories of «body», «boundary» and «hierarchy» meet at once; the fantastic hole.

\section{The Fantastic Hole as Trope of the Fantastic of Space}

The concern of the fantastic since its origins in the positivistic era of the late 18th century has been to give voice to precisely that which the discourse of reason could not codify. A visual and textual image that very clearly illustrates this concern is the hole, an image that recurs in the fantastic text from its origins to its postmodern manifestations. As Neus Rotger has suggested (2003), the figure of the hole embodies the subversive essence of the fantastic in that it perforates the rational discourse of the positivistic conception of reality that predominated during the eighteenth and nineteenth centuries. The fantastic hole reveals the inconsistencies of a (supposedly) coherent and 
solid structure. This metaphorical relation between the perforation and the fantastic makes this motif an archetype of the «fantastic of space».

The most common understanding of the word «hole» relates to cavities in material structures. The first entry of the Collins English Dictionary is «perforation of a solid surface» and similarly the Oxford English Dictionary gives «a hollow place, cavity, excavation». Extended, this definition can be applied to biological structures; that is, an empty hollow space in an existent organ (Oxford English Dictionary). The issue of biological voids and psychoanalytical theory is extensively discussed in «The Uncanny» by Freud (1919), where he points to the symbolic potential of holes: their multiplicity of meanings can evoke anxiety, in particular because of their lack of explicit reference or «void». Leaving aside this psychoanalytical approach, Freud rightly suggests that the figure of the hole recalls a presence through the ascertainment of its absence; it is precisely this oscillation between absence and presence, not as dichotomy but rather as coexisting principles, that renders the hole a transgressive figure in the human imaginary. ${ }^{7}$

Of use in elaborating on this aspect is Michel Foucault's concept of «heterotopia». In his essay «Des Espaces Autres» (1967) he analyses the way different civilisations have dealt in spatial terms with the «different» or «extraordinary». According to Foucault, this has been carried out by situating the different and extraordinary in what he calls «heterotopias», these being physical containers (with or without clear geographical markers) where «individuals whose behaviour is deviant in relation to the required mean or norm are placed» (Foucault, 1986: 25). Heterotopias are places allocated by society to individuals in a state of crisis (death and cemeteries, madness and psychiatrics, etc.). However, Foucault's use of the heterotopia relates to the socio-historical dimension and not to the literary one. For this reason, the more restricted notion of «fantastic hole» as archetypical image of the «fantastic of space» is preferred in this article, which nevertheless draws from the Foucauldian heterotopia.

The fantastic hole can be understood as a heterotopic figure in that it is the physical form of the non-empirically perceptive or rationalised: that which does not fit within a given socio-cultural frame. Furthermore, it is a liminal space which transgresses binaries, articulating absence and presence, oscillating between the lack of meaning and the excess of it.

7 Note the parallels with Grivel's conception of the fantastic as «arising from the visual crumbling of a place previously conceived as full: the place does not hold, one knows, its substance dissipates, wilts, disintegrates.» (Grivel in Founier Kiss, 2007: 143). 
There are various examples of how in history man has dealt with the supernatural in a «heterotopic» way. In some Ancient cosmologies, the hole was a symbolic projection of the unknown. What could not be explained was assigned a space, both devoid of specific referents and below or beyond the visible confines of the territory but at the same time a constituent part of it. This is, for example, Anaximander's model of the universe as consisting of a dark boundary (the sky) pierced through by holes (stars) that were seen as windows revealing a mysterious fire beyond it. Another example is the Roman Mundus («world» in Latin), a cavity in which the «supernatural» was safely contained. This was a circular trench excavated for ghosts, spirits and other non-human creatures to be literally «buried», with the exception of three times a year when this receptacle of the supernatural was ceremonially opened for the spirit of the dead to come among the living and to reconcile the two worlds (Rykwert, 1988: 59). The Mundus very clearly exemplifies the relationship between the notion of hole as boundary to distinguish and isolate the supernatural.

\section{a) Body:}

In the fantastic the hole is the trope in which the spatial transgressions of body, boundary and hierarchy converge. In a large variety of texts, the fantastic hole engulfs the human body, removing the subject from ordinary reality. An example is Joe Hill's «Voluntary Committal» (2005). In this story, set in a completely realistic environment, a child builds a cardboard construction. He who enters has never returned. This same text also challenges the logical hierarchical relations between spaces, further discussed below in section C). The cardboard tunnel of «Voluntary Committal» is not only a «black hole» in the sense that it swallows up he who steps into it but it also potentially leads the character to unexplored parallel dimensions.

Holes that distort the notion of corporeal position are also found in «Mi hermana Elba» (Cristina Fernández Cubas, 1980). In this story the narrator, Elba's sister, finds her old diary after a long time. In it she had described her childhood with the now dead Elba. After their parents' divorce the two girls had to go to an isolated boarding school. There, in the company of another student, Fátima, they find some areas that are invisible to the rest of the students and that make them invisible from the rest. The convent is a rigidly structured space, both by physical frontiers (e.g. the outside fence, the closed order's door, permitted and prohibited zones) and by disciplinary reg- 
ulations. And so these hideouts are portrayed as an extension beyond their confined framed space; they are «worlds without limits» (Fernández Cubas, 2008: 67) and «refuges» where the girls have «a strange immunity» (2008: 66). But most importantly, these are the spaces of alterity against the norm. It is in this last aspect that the discourse of the fantastic is located. From the start, the existence of these spaces is incomprehensible to the narrator and not viewed as a natural part of her environment. These «mysterious conduits whose understanding escaped [them]» (2008: 66) challenge the discourse of reason: «All sorts of images of the dangerous adventure I just lived were still spinning in my head but, above all, a large amount of questions for which, no matter how hard I tried, I couldn't find any satisfactory answer» (2008: 65).

Since these spaces constitute a referential void, they have no precise word allocated to them in our compendium of signifiers. As a result, their referentiality is constructed through the technique of catachresis: they are assigned a term of something existing in the actual real world that bears physical and conceptual resemblance to them. In this respect, note the variety of catachrestic designations to refer to these spaces: «hideouts» (2008: 66), «conduits» (2008: 66), «paths» (2008: 67) or «refuges» (2008: 69). The distortion of the sense of physical position is best captured in a sentence in which Fátima seeks to «explain» the phenomenon of these hideouts: "We were there but we weren't. Even if you thought we were there, we weren't there" (2008: 65). These spaces cancel spatial dichotomies, in this case the location here-there, by being both simultaneously. The illogical concatenation of the two statements evacuates the reference of the adverb of place «there». Where is «there»? The reader cannot establish the specific emplacement of the character since the holes are neither here nor there.

\section{b) Boundary:}

The fantastic hole also challenges the ordinary framing function of physical space since it perforates what in extratextual reality would be an even, solid space. The representation of this perforation of human reason often coincides with the metaphor of a physical structure that disappears: an unexpected hole in material space, a crack in the discourse of reason. This is the case of the house of «La casa feliz» (José María Merino, 2004), a building that disappears as it pleases just when it is about to be inhabited. This nomadic structure refuses to be bound to the physical laws that anchor it to the ground. Another illustrative example is «L'Érreur» (1974) by Belgium Jacques Sternberg, a text that tells of a man who returns home to realise that his buil- 
ding, number 64, has disappeared. On his street, number 62 is now adjacent to number 66. Even in the unlikely event that his house was demolished during the day, there should be an empty surface between 62 and 66 indicating that his building once took up space. The fantastic hole, thus, is not only the absence of the building but that impossible cancellation of space between the neighbouring buildings 62 and 66. What is remarkable is how the character tries to make sense of the fantastic event by attributing it to a trick played by his mind, «an error on his conscience, something forgotten» («L'Érreur», Sternberng, 1998: 94), as if a loophole in the structure of his memory had been projected onto physical reality. Therefore, the fantastic hole is not only present in physical space but may be viewed as a flaw of his mind, consisting of multiple mental «slippages». This presents an interesting inversion of the traditional fantastic scheme that portrays a character as a victim of the impossible occurrence, to a subject who is at least partially also a causing agent of the fantastic; in other words, a subject who is conscious of his own limitations in the apprehension of the real.

The hole is also visible in a classic motif of the fantastic that can be identified as «the pierced map», namely when the place in question is nowhere to be found in maps: it is a void in the referential space to which the map alludes. This is the case, for example, of Castle Dracula (1847), of the Rue d'Auseuil («The Music of Erich Zann», Lovecraft, 1922) and of the village of Innsmouth («The Shadow Over Innsmouth», Lovecraft, 1931).

I was not able to light on any map or work giving the exact locality of the Castle Dracula, as there are no maps of this country as yet to compare with our own Ordnance Survey Maps. (Dracula, Stoker, 2003: 6)

I have examined maps of the city with the greatest care, yet have never again found the Rue d'Auseil. These maps have not been modern maps alone, for I know that names change. I have, on the contrary, delved deeply into all the antiquities of the place, and have personally explored every region, of whatever name, which could possibly answer to the street I know as the Rue d'Auseuil. («The Music of Erich Zann», Lovecraft, 1984: 56)

Any reference to a town not shewn on common maps or listed in recent guide-books would have interested me, and the agent's odd manner of allusion roused something like real curiosity. («The Shadow Over Innsmouth», Lovecraft 1993: 217)

c) Hierarchy:

Third, the fantastic hole plays upon an inversion of logical spatial hierarchies, since its inside could be unexpectedly larger than its external 
dimensions. Because the hole hides, it evokes. This idea of potentiality heightened by an «excess of meaning» can be interpreted in the Heideggerian sense. The fantastic holes can be regarded as potential sources of anxiety since they frame an absence (physical, ontological, epistemological). As the German philosopher suggested, «[a] boundary is not that at which something stops but, as the Greeks recognised, the boundary is that from which something begins its presencing» (Heidegger, in Bhabha, 1994: 1). This also relates to Bertrand Westphal's statement that «to point at/to demarcate [signaler, in theFrench original] emptiness, it is to start filling it» (2011b: 77).

Precisely this is the central theme of «La casa ciega» (David Roas, 2010). The character becomes obsessed with the inside of a boarded house he sees from the train in his regular journey to work. Anxiety increases when he realises, through his binoculars, that the boarded windows and doors of the house are fake, painted on the surface. The boarded house functions as some sort of Pandora's box. Even if the story cannot be said to be strictly from the fantastic, since there is nothing explicitly impossible, the protagonist's fear is symptomatic of an ontological uncertainty related to that which he cannot see: the constricted space of the house functions as an empty and blind hole on which to project a multitude of possibilities.

\section{CONCLUSION}

The aim of this article has been to establish the theoretical foundations of a phenomenon where fantastic transgression was directly interlinked with the dimension of space represented in the literary text. This phenomenon, also labelled here as «the fantastic of space», has been explored in relation to three categories: fantastic transgressions of the body in space, transgressions of spatial boundaries and transgressions of spatial hierarchy. These are fundamental phenomenological and philosophical aspects that intervene in the human apprehension of reality. Furthermore, these spatial categories are three basic elements that play a central role in the construction of literary realism and relate to other narratological categories such as «character» (for body), «frame» (for boundary) and «organisation» of the elements in the storyworld (for hierarchy). These three thematic lines are distinct and yet complementary and provide a structure for derivative transgressions related to space, such as the physical disappearance of spaces, animations of buildings, or obliteration of distances, volumes and dimensions. 
Finally, the figure of the fantastic hole has been introduced as a paradigm of the «fantastic of space». As explored through the various examples of the traditional and postmodern fantastic, this figure merges the three categories. The hole is then, in my view, the fantastic trope which best captures how the changes of corporeal position, architectural boundaries and spatial hierarchies within the text de-automatise the reader's relationship to space, transgressing the illusion of verisimilitude.

BIBLIOGRAPHY

Abuenque, P. (1962): Le Problème de l'être chez Aristote, PUF, Paris.

Adolph, J.B. (2009): «La casa», in G. Portals Zubiate (ed.), La estirpe del ensueño, El lampero alucinado ediciones, Lima.

Aguirre, M. (1990): The Closed Space: Horror Literature and Western Symbolism, Manchester University Press, Manchester.

Álvarez Méndez, N. (2002): Espacios narrativos, Universidad de León, Secretariado de Publicaciones y Medios Audiovisuales, León.

BAllard, J.G. (2006): «The Enormous Space», in The Complete Short Stories: Volume Two. Harper, London.

BARTH, J. (1969): Lost in the Funhouse: Fiction for Print, Tape, Live Voice, Secker \& Warburg, London.

Bнавна, H.K. (1994): The Location of Culture, Routledge, London.

Bollnow, O.F. (2011): Human Space, Hyphen, London.

Borges, J.L. (1999): Collected Fictions, Allen Lane, London,.

Brooke-Rose, C. (1981): A Rhetoric of the Unreal, Cambridge University Press, Cambridge.

Clapin, J. (2008): Skhizein, Dark Prince, France.

CAMpra, R. (2001): «Lo fantástico: una isotopía de la transgresión», in D. Roas (ed.), Teorías de los fantástico, Arco/Libros, Madrid, pp. 153-192.

CASAS, A. (2010): «Transgresión lingüística y microrrelato fantástico», Ínsula, nº 765, pp. 10-13.

Cortázar, J. (1964): «Continuidad de los parques», in Final del juego. Sudamericana, Buenos Aires.

Doležel, L. (1998): Heterocosmica: Fiction and Possible Worlds, Johns Hopkins University Press, Baltimore, London.

Dostoyevsky, F. (2000): Crime and Punishment, Wordsworth Classics, London.

Dufour, M. (1991): «Le Corps éparpillé», in Passé la frontière, L'Instant Même, Québec.

ERDAL JoRDAN, M. (1998): La narrativa fantástica: evolución del género y su relación con las concepciones del lenguaje, Iberoamericana, Madrid. 
FAYE, É. (1997): «Tandis que roule le train», in Je suis le gardien du phare, José Corti, Paris.

Fernández Cubas, C. (2008): «Mi hermana Elba», in Todos los cuentos, Tusquets, Barcelona.

Ferrer-Bermejo, J. (1982): «Dejen salir», in Incidente en Atocha, Ediciones Alfaguara, Madrid.

Foucault, M. (1986): «Of Other Spaces», Diacritics, vol. 16, no. 1, pp. 22-27.

FourNiER KIss, C. (2007): La Ville européenne dans la littérature fantastique du tournant du siècle, (1860-1915), Age d'homme, Lausanne.

Freud, S. (2003): The Uncanny, Penguin, London.

García, P. (2013a): «El espacio como sujeto fantástico: el ejemplo de "Los palafitos" (Ángel Olgoso, 2007)», Pasavento. Revista de Estudios Hispánicos, vol. I, no. 1, pp. 113-124.

(2013b): «The Fantastic of Place versus the Fantastic of Space», Revista Letras $\mathcal{E}$ Letras, Vol. 29, n. 1, pp. 97-110.

Hallet, W. \& B. Neumann (eds.) (2009): Raum und Bewegung in der Literatur: die Literaturwissenschaften und der Spatial Turn, Transcript, Bielefeld.

Harvey, D. (1990): The Condition of Postmodernity, Basil Blackwell, Oxford.

Heidegger, M. (1971): «Building, Dwelling, Thinking», in Poetry, Language, Thought, Harper Colophon Books, New York.

Hill, J. (2005): «Voluntary Committal», in 20th Century Ghosts, Gollancz, London.

Hoffmann, E.T.A. (1982): «The Deserted House», in Tales of Hoffmann, Penguin, Harmondsworth.

Honstкотte, M. (2004): The Postmodern Fantastic in Contemporary British Fiction, Wissenshaftlicher Verlag Trier, Trier.

IWASAKI, F. (2004): «La habitación maldita», in Ajuar funerario, Páginas de Espuma, Madrid.

JACKSON, R. (1981): Fantasy: the Literature of Subversion, Methuen, London.

JaCKSON, S. (1999): The Haunting of Hill House, Robinson, London.

Lovecraft, H.P. (1984): The Dunwich Horror and Others, Arkham House, Sauk City. (1993): The Shadow over Innsmouth, Penguin, London.

MERINO, J.M. (1982): Cuentos del reino secreto, Alfaguara, Madrid.

(2002): Días imaginarios, Seix Barral, Barcelona.

(2004): Cuentos de los días raros, Alfaguara, Madrid.

Merleau-Ponty, M. (1962): Phenomenology of Perception, Routledge \& Kegan Paul, London.

Monzó, Q. (1996): «La força centrípeda», in Guadalajara, Open Letter, New York \& Rochester.

Moretti, F. (1998): Atlas of the European novel, 1800-1900, Verso, London.

Pavel, T.G. (1986): Fictional Worlds, Harvard University Press, Cambridge, Mass.

Pimentel, L.A. (2001): El espacio en la ficción: la representación del espacio en los textos narrativos, Siglo XXI, México F. D.

Roas, D. (ed.) (2001): Teorías de lo fantástico, Arco/Libros, Madrid. (2010): Distorsiones, Páginas de espuma, Madrid. 
(2011): Tras los limites de lo real: una definición de lo fantástico, Páginas de Espuma, Madrid.

Rodríguez HERNÁNDEZ, T. (2010): «La conspiración fantástica: una aproximación lingüístico-cognitiva a la evolución del género», Espéculo. Revista de estudios literarios, $\mathrm{n}^{\circ} .43$.

Rotger, N. (2002): La configuración del límite en la literatura fantástica, Universitat Autònoma de Barcelona [M.A. Thesis].

Ryan, M. (1991): Possible Worlds, Artificial Intelligence and Narrative Theory, Indiana University Press, Bloominton.

(2013): «Space», en P. Hühn et al. (eds.), The Living Handbook of Narratology. Hamburg: Hamburg University Press. URL = hup.sub.uni-hamburg.de/lhn/index. php?title=Space\&oldid $=1708$ [view date: 15 Feb 2013].

RYKweRT, J. (1988): The Idea of a Town: the Anthropology of Urban Form in Rome, Italy and the Ancient World, Princeton University Press, New Jersey.

Sternierg, J. (1998): Contes glacés, Labor, Brussels.

StOKeR, B. (2011): Dracula, Barnes \& Noble, New York.

TALLy, R.J. (2011): Geocritical Explorations: Space, Place, and Mapping in Literary and Cultural Studies, Palgrave Macmillan, New York, Basingstoke.

Vigalondo, N. (2009): Marisa, Arsénico Producciones, España.

Wells, H.G. (2013): «The Crystal Egg». Electronic Text Center, University of Virginia Library. Available: http://etext.virginia.edu/etcbin/toccer-new2?id=WelCrys. sgm\&images=images/modeng\&data $=/$ texts/english/modeng/parsed\&tag $=p$ ublic\&part=1\&division $=$ div1 [view date: 15 . Feb. 2013]

Westphal, B. (2011a): Geocriticism: Real and Fictional Spaces, Palgrave Macmillan, New York.

(2011b): Le Monde plausible: espace, lieu, carte, Éditions de Minuit, Paris. 